\title{
MEMOIR
}

\section{ARTHUR HERBERT SHREWSBURY}

Arthur Herbert Shrewsbury died on 7 October 1972, at the age of 75 . Born on 2 August 1897, he was educated at The John Lyon School, Harrow, where he was regarded by his mathematics master-subsequently Head Master for 25 years and still very much aliveas one of his most brilliant pupils. A foot injury debarred Shrewsbury from Active Service in the First World War and after leaving school in 1915, he continued actuarial studies with Hampson's classes in Chancery Lane. In 1917, he commenced his career in the London \& Lancashire Life and General Insurance Company-subsequently known as the London \& Scottish Insurance Corporation-and transferred to the Royal Exchange Assurance in 1920. Five years later, he having qualified as a Fellow in 1922, the Royal Exchange appointed Shrewsbury Actuary of the British Equitable, a life company which the Royal Exchange had acquired with their take-over of the State Insurance Group in 1924 and which was in urgent need of invigoration.

At this time Shrewsbury lived at Chesham Bois, near to Sir William Elderton, with whom he developed a close friendship, and six years later he was chosen by the London $\&$ Lancashire Insurance Group, acting with Sir William's advice, to become the principal officer of their subsidiary company, the Law Union \& Rock, another company in serious need of rehabilitation. Shrewsbury was firstly appointed an Assistant Secretary in 1931, to accede to the principal position of Secretary \& Actuary-subsequently called Manager \& Actuary-a few months later in 1932. This position he held until his retirement in 1959. Thus, a career which commenced in one London \& Lancashire Insurance Company matured and terminated in another quite different Insurance Group under the same name.

The state of affairs in the Law Union in 1932 presented a challenge which Shrewsbury accepted wholeheartedly. Immediate steps were taken to increase and rejuvenate the actuarial staff by the appointment of a number of actuarial students direct from school and an overhaul of the valuation system included the introduction of one of the earlier Powers Samas tabulating installations. Overhaul of the investment portfolio, however, was to exercise Shrewsbury considerably for many years. This, coupled with the loss immediately the Second World War commenced of almost all the young actuarial staff-they were members of the volunteer forces-just when the benefit of their training was beginning to show, makes it all the more remarkable that he did so much for both the Institute and the Life Offices' Association.

In the service of the Institute, Shrewsbury was an Examiner in 1929, Secretary of the Board of Examiners from 1930 to 1934, Assistant Editor of the Journal in 1937 and 1938 and Editor from 1938 to 1943 . He was a member of Council for 15 years between 1933 and 1950, being Honorary Secretary from 1936 to 1938, Vice-President from 1938 to 1941 and Treasurer from 1946 to 1948 . In 1948 he was appointed chairman of a small committee of three to examine the papers submitted to the Institute's Centenary Congress, to adjudicate thereon for the purpose of the prize awards and to prepare the Centenary Volumes. He submitted only one paper to a sessional meeting - in 1943-but that paper, entitled 'Income Tax as affecting Life Assurance Offices (J.I.A. 72, 35) became a taxation classic which the writer of this note found morc than ten years later still on the desks of senior principal Inspectors of Taxes and used by them as a life company taxation manual.

In the Life Offices' Association, Shrewsbury's first appointment was to the Taxation Committee in 1938 and thereafter his membership of committees of one kind or anoiher was virtually continuous for 15 years: during that time he served on no less than 24 committees. Of particular note is his service to the Association in the taxation field and in the crucial period of the Second World War and its immediate aftermath. He was Chairman of the Taxation Committe from 1939 to 1943 and again in 1947; Chairman of the War Emergency Committee from 1943 to 1946; Chairman of the Life Assurance (War Settlement) Committee from 1943 to 
1947 and Chairman of the whole Association in 1943 and 1944-all very important offices in an exceptionally important period of life assurance history. In fact it can be said that Shrewsbury was as influential as any in guiding the life assurance industry through the intricacies of E.P.T., N.D.C. and other war-time controls and in securing for the industry the very significant benefit of the 'pegged' rate of income tax $\left(37 \frac{1}{2} \%\right)$ on interest income-a benefit which even today is to some extent still enjoyed.

In almost everything, Shrewsbury was a perfectionist and his masterly accomplishments in the actuarial and life assurance spheres were probably more due to an infinite capacity for taking pains than to an innate super excellence. This, coupled with such a formidable list of professional achievements, left him little time for outside interests. In his earlier years he was a keen walker, spending several holidays walking in the Black Forest in Germany and around the coast of Britain and he regarded golf courses, particularly those on the coast, as polluters of the environment because of their interference with otherwise natural surroundings. His principal hobby, however, was gardening but even in that it is doubtful whether his aim at perfection allowed him the true relaxation which he might otherwise have enjoyed. Perhaps, therefore, an early setback in health was to be expected. Shrewsbury was not robust and those strenuous ten years from the outbreak of war in 1939 to the completion of the Centenary Volumes in 1949 certainly took their toll. In October 1949 he suffered the first of a series of five attacks of coronary thrombosis. The first three were in rapid succession and kept him from his desk for a year: he returned to work with all his accustomed energy and a fourth attack ensued. This time an anti-coagulant treatment was applied and Shrewsbury again resumed his previous activities to the full but a fifth attack forced him to accept defeat. By the end of 1954 he had relinquished all his activities in both the Institute and Life Offices' Association affairs

With his tall stature, topped by a high domed and prematurely bald head, his bifocal, gold rimmed spectacles and a natural reserve, Shrewsbury presented a most distinguished though perhaps rather severe appearance and the modern vogue of Christian name familiarity amongst business associates was foreign to his nature. Within the shell, however, was a rather shy but very kindly disposition, always willing to help when help was really needed and he certainly had the ability to breathe life into an ailing administration. A number of actuaries who commenced their careers in the 'British Equitable' recently held a reunion dinner and paid Shrewsbury the compliment of sending him an autographed menu card with their thanks to him for having 'made the B.E. a fit place to start a career in'. The actuaries who commenced careers under his command at the "Law Union' owe him similar gratitude.

It seems rather a tragedy that so devoted a member of the Institute should have been deprived, through ill-health, from attaining the highest office which otherwise would appear to have been his due, but his wife, Maisie, who survives him and in the past had to share him so much with professional affairs, may perhaps feel grateful for the later years of greater leisure which fate decreed. Certainly during those later years, under her devoted and closer surveillance, Shrewsbury relaxed and mellowed very considerably.

Shrewsbury will be remembered with great respect by all who knew him and with love and affection as well by those privileged to work with him in close collaboration.

J. H. KITTON 